\title{
Keynes és White szerepe a Nemzetközi Valutaalap létrehozásában és a Bretton Woods-i értekezlet
}

\begin{abstract}
A szerzőnek ugyancsaka Közgazdasági Szemlében megjelent előző cikke (Szakolczai [2016]) Keynes életútjával foglalkozott élete utolsó szakaszáig, a második világháborúig, ennek a cikknek a tárgya pedig a Nemzetközi Valutaalap megalakításának előkészítése és a Bretton Woods-i értekezlet, benne Keynes szerepe. Mindkét cikk vezérfonala, hogy Keynes egész tevékenysége és összes múve nyílegyenesen mutat utolsó vállalkozása és utolsó munkája: a Nemzetközi Valutaalap létrehozása és a nemzetközi gazdaság keynesi rendjének kialakítása felé. Ez ugyanolyan fontos, mint a keynesi általános elmélet, és joggal nevezhető Keynes általános nemzetközi elméletének. Mint köztudomású, Keynes Bretton Woodsban nem tudta elfogadtatni javaslatait; az ott tető alá hozott megállapodás nagyrészt az amerikai nézeteket megfogalmazó és képviselő Harry Dexter White elképzeléseinek felelt meg ezért itt egyaránt szó lesz Keynes és White nézeteiről.

Journal of Economic Literature (JEL) kód: B17, B31, F33, N10.
\end{abstract}

A tanulmány - amely folytatása a Keynes második világháborúig tartó életútját tárgyaló Szakolczai [2016] írásnak - a Nemzetközi Valutaalap megalakításának elökészítésével és a Bretton Woods-i értekezlettel foglalkozik. A szerző mindkét cikkben azt a nézetet képviseli, hogy Keynes egész tevékenysége és összes müve nyílegyenesen mutat utolsó vállalkozása és utolsó munkája: a Nemzetközi Valutaalap létrehozása és a nemzetközi gazdaság keynesi rendjének kialakítása felé. Ez ugyanolyan fontos, mint a keynesi általános elmélet, és joggal nevezhető a keynesi általános nemzetközi elméletnek. Keynes azonban Bretton Woodsban nem tudta elfogadtatni javaslatai egészét - az ott kialakított megállapodás nagyrészt az Egyesült Államok nézeteit megfogalmazó és képviselő Harry Dexter White elképzeléseinek felelt meg. Ezért itt párhuzamosan és azonos súllyal kell foglalkozni Keynes és White nézeteivel. ${ }^{1}$

\footnotetext{
${ }^{1}$ A Bretton Woodsban nem rendezett kérdések megoldására 1946-ban, Savannah-ban került sor. Az ott létrehozott kiegészítő megállapodásokkal, Keynes és White tragikus halálával és a Bretton Woods-i megállapodás összeomlásával a szerző más írása fog foglalkozni.
}

Szakolczai György, a közgazdaság-tudomány kandidátusa.

A kézirat első változata 2016. szeptember 26-án érkezett szerkesztőségünkbe.

DOI: http://dx.doi.org/10.18414/KSZ.2017.1.74 
Az itt tárgyaltak szinte ismeretlenek a nagyközönség előtt, mert csak Keynes összegyüjtött írásaiból, valamint a Valutaalapról folytatott angol-amerikai, majd nemzetközi tárgyalások anyagaiból ismerhetők meg. Ezek nagy késéssel jelentek meg: Keynes összegyüjtött írásainak harminc kötete 1971 és 1989 között (Keynes [1906-1946/1971-1989]), e sorozatnak ezzel a korral foglalkozó kötetei csak 1979-1980-ban, vagyis egy teljes generációval az események után (Keynes [19401944/1980], [1941/1946/1980], [1944-1946/1979]). Az IMF hivatalos történetíróinak kötetei (Horsefield [1969a], [1969b], de Vries-Horsefield [1969]) valamivel korábban, de mégis több mint húsz évvel az események után láttak napvilágot, amelyek - első látásra elvesztve aktualitásukat - akkoriban nem keltettek feltűnést. Keynes első életrajza (Harrod [1982]) 1951-ben a Keynes család megrendelésére gyorsan megjelent ugyan, de irreális, idealizált képet rajzolt Keynesről. Nagy késéssel látott napvilágot a többi életrajz (1976-ban a Moggridge [1992], [1993], 1983-ban a Skidelsky [1992], majd 1992-ben a Skidelsky [2000a], a kétezres évek elején a Skidelsky [2000b], [2005]). Keynes teljes és valósághủ életrajzának csak Skidelsky tekinthető, amiért Skidelsky óriási elismerést és lordságot is kapott. Az itt vizsgált korral foglalkozó III. kötet több mint fél évszázaddal az események után jelent meg. Az események másik főszereplöjére, White-ra vonatkozó információk szinte egyetlen forrása Rees [1973] életrajza, amelyet közel harminc évvel az itt tárgyalt időszak után adtak ki. Mindezek miatt ezek a hetven évvel ezelőtti és a ma követendő gazdaságpolitika szempontjából is végtelenül fontos nézetek és események szinte teljesen ismeretlenek még a jól tájékozott közgazdászok körében is.

A Valutaalap elemzésének legfontosabb kiindulópontja hat - Horsefield [1969b] által közölt - dokumentum: Keynes és White javaslatának két-két változata, az ezek egyeztetése során létrejött közös nyilatkozat és a Bretton Woodsban elfogadott megállapodás. E cikk mondanivalójának megértéséhez elengedhetetlen e dokumentumok ismerete, ezért kissé rövidített formában hozzáférhetővé tesszük őket a tanulmány elektronikus Mellékletében. ${ }^{2}$

\section{Keynes gondolatrendszerének kialakulása}

Keynes az első világháború elején kalandos körülmények között került a pénzügyminisztériumba. A második világháború elején viszont azonnal meghívták, és 1940 augusztusától 1946-ban bekövetkezett haláláig formálisan csupán a pénzügyminiszter fizetés nélküli részmunkaidős tanácsadójaként dolgozott, de óriási volt a befolyása. Még azt is mondták, hogy „ö volt a pénzügyminisztérium”.

Az itt kifejtendő gondolatrendszer alapelemei már megvoltak a Treatise on Money második kötetének utolsó fejezeteiben (Keynes [1930]), az ismételt megfogalmazás azonban szinte véletlenszerüen kezdődött. A német-angol propagandaháborúban

\footnotetext{
${ }^{2}$ A tanulmány elektronikus Melléklete elérhető a http://sparc.core.hu/ soko/F-SZGY201701.pdf linken. A mellékletben idézett szemelvények teljes szövege elérhető: Horsefield [1969b] (http://www. elibrary.imf.org/staticfiles/IMF_History/IMF_45-65_vol3.pdf).
} 
angol részről először azt a nézetet képviselték, hogy a második világháború után vissza kell térni az első világháború előtti nemzetközi pénzügyi rendszerhez. Keynes ezt határozottan elutasította (Keynes [1940-1944/1980] 1-2. o.]), és úgy vélte, az indiai valutaproblémákról írt könyvének (Keynes [1913]) szellemében „nem [szabad] javasolnunk a háború előtti rendszernek megfelelö laissez faire valutáris megállapodásokhoz való visszatérést" (8-9. o.). Ebben a szellemben fogalmazta meg az elképzeléseit áttekinthető formában elöször bemutató előzetes nyilatkozatot (Keynes [1941a]), amely a következőképpen kezdődik: „A versailles-i békeszerződés megalkotói elkövették azt a hibát, hogy elhanyagolták Európa gazdasági újjáépítését. [...] A brit kormány szilárd elhatározása, hogy nem követi el újra ezt a hibát. [...] Az összes európai ország népének közjóléte lesz a mi politikánk külföldön éppúgy, mint itthon." (11. o.) Ez a Béke gazdasági következményeinek (Keynes [1919/1971]), valamint az Általános elméletnek (Keynes [1936/1965]) a szelleme - vagyis Keynes életmüve egységes egész.

Keynes azonnal megpróbált politikai támogatást szerezni az előzetes nyilatkozatnak. Véleményezte tervezetét a brit pénzügyminisztérium, a Bank of England, a külügyminisztérium és a gazdasági hadviselési minisztérium (Ministry of Economic Warfare). 1941 januárjában megtárgyalta ezt a tervet Harry Hopkinsszal, Roosevelt elnök három legbelsőbb tanácsadójának egyikével. A terv ezt követően, 1941. január 30-án Churchill elé került, aki enyhítette ugyan a javaslatok megfogalmazásának radikalizmusát, de összességében jóváhagyta a dokumentumot. Keynes ezt követően Washingtonban tárgyalt elképzeléseiről. A következő irat, az első memorandum - Háború utáni valutapolitika címen (Keynes [1941b]) - szeptemberre készült el, és novemberre a második memorandum, amely a konkrét javaslatok első változatát mutatta be (Keynes [1941c]).

A Háború utáni valutapolitika címủ memorandum a következő meglepő mondatokkal kezdődik: „Amióta a pénz és az értékpapírok léptek a cserekereskedelem helyébe, még sohasem sikerült megoldani azt a problémát, hogy miként tartsák fenn az országok közti fizetési mérleg egyensúlyát. [...] Az ennek a problémának a megoldására való képtelenség mindmáig fontos oka volt az elszegényedésnek, a társadalmi elégedetlenségnek, sőt még a háborúknak és a forradalmaknak is. A legutóbbi ötszáz év folyamán csak két, mindkét esetben mintegy ötvenéves időszak volt (az angol kronológia szerint Erzsébet és Viktória kora), amelyröl azt mondhatjuk, hogy a nemzetközi kereskedelemnek a pénz felhasználásával való lebonyolítása »müködött «. [...] A 19. század második felében azért [müködött], mert [...] a nemzetközi beruházások Londonra alapozott rendje áttette a korrekció terhét az adósok pozíciójában lévőkről a hitelezők pozíciójában lévőkre.” (Keynes [1941b] 21. o.) „Annak a feltételezése, hogy létezik egy olyan simán müködő automatikus korrekciós mechanizmus, amely fenntartja az egyensúlyt, ha rábízzuk magunkat a laissez faire módszereire, doktriner illúzió, amely anélkül hagyja figyelmen kívül a történelmi tapasztalatokat, hogy ezt bármiféle megbízható elmélet is alátámasztaná." (Uo. 21-22. o.) E két alapvető fontosságú tétel szöges ellentétben van az akkori, sőt mai bevett nézetekkel, és ezek a később kifejtendő javaslatok alapelvei. 
Keynes szerint tévesek azok az elképzelések, hogy a) a szabadon lebegő valutaárfolyamok önmaguk egyensúlyi helyzetének megtalálására vezetnek; hogy b) a hitelező és az adós országok közti szabad hitel- és kölcsönmegállapodások egyensúlyra vezetnek; ez a 19. századi helyzet hamis analógiája; hogy c) az arany szabad áramlása [a mai helyzetben a nemzetközi tőkeforgalom szabadsága] az árszintek és a gazdasági tevékenység olyan korrekcióira vezet a hitelfelvevő országokban, amelyek megszüntetik a rájuk nehezedő nyomást; hogy $d$ ) a defláció és ami még rosszabb, a kompetitív defláció a bér- és árindexek olyan korrekcióira vezet, amelyek képesek az áruforgalom átirányítására; hogy e) a tudatosan végrehajtott valutaleértékelés, valamint ami még rosszabb, a kompetitív leértékelés alkalmas eszköz ugyanezen cél elérésére; továbbá hogy $f$ ) a vámok, kedvezmények és támogatások et hoc genus omne helyreállítják a nemzetközi kereskedelem egyensúlyát restrikció és diszkrimináció útján (uo. 22-23. o.). Ezek a tételek ismét alapvető fontosságúak, sőt a későbbiekben bemutatandó rendszer alapelvei.

Végül, mintha a mai világról lenne szó: „A jelen háborút megelőző második fázisban teljes degeneráció következett be, és a tőke azokból az országokból, amelyeknek kereskedelmi mérlege kedvezőtlen helyzetben volt, azokba áramlott, ahol kedvezö volt ennek helyzete. [...] A [rossz pénzügyi helyzetben lévő országokból] kimenekülő és spekulatív tőkének ehhez való hozzáadódása vezetett az egész rendszer összeomlására. [...] A »jobb befektetés« holléte a repülő szőnyeg sebességével tolódik el. Szabad tőkék száguldanak a világ körül, szétzilálva minden stabil vállalkozást. [Ezért] semmi sem biztosabb, mint hogy a [nemzetközi] tökeforgalmat szabályozni kell - ami már önmagában is a laissez faire berendezkedéstől való messzemenő eltéréseket von maga után" (uo. 30-31. o.). Mindez a bevett, máig is domináns elvek teljes elutasítása.

E javaslatok végleges változata (Keynes [1942a]) a brit kormány hivatalos álláspontjává vált. Ezt az anyagot megküldték az amerikaiaknak, és ez lett az angol-amerikai tárgyalási dokumentumokat összefoglaló kötet első tétele (Keynes [1942b]).

\section{White életpályájának kezdete}

Keynes származása és élete világosan mutatja, milyen mérhetetlen energiák szabadulnak föl azokban a családokban és társadalmi csoportokban, amelyeknek hoszszú időn át megkülönböztetést és elnyomatást kellett elszenvedniük. Amit azonban Keynes nonkonformista öseinek Angliában kellett elszenvedniük, semmi sem volt ahhoz képest, amit White őseinek kellett elviselniük a cári Oroszországban. Emellett Keynes családjának fölemelkedése már az ő nagyszüleinek idejében megkezdődött, White viszont saját erejéből, egyetlen emberöltő folyamán tette meg az utat a mélyből a csúcsig. Ez példátlan teljesítmény kiemelkedő képességeinek és óriási akaraterejének az eredménye.

White apja 1860-ban született. 1885-ben érkezett Bostonba, 1992-ben alapította meg családi vaskereskedésüket, ugyanebben évben kapták meg az amerikai állampolgárságot, és ugyanezen évben született legkisebb gyermekük, Harry. Harry még 
10 éves sem volt, amikor elvesztette anyját, és 17, amikor apját is. 1917 áprilisáig „keményen dolgozó vaskereskedő” volt. A fölemelkedés lehetőségét az első világháború adta meg számára. 1917-ben azonnal jelentkezett katonai szolgálatra. Franciaországba utazása előtt megházasodott, hazaérkezése után, 1919-ben elhagyta a családi üzletet, és 1922-ben beiratkozott New Yorkban a Columbia Egyetemre. Itt államtudományt tanult, 1923 nyarán ment át a Stanford Egyetemre, Palo Altóba, és ott már közgazdaságtannal foglalkozott. Kiváló eredményeket ért el, 1923-ban szerezte meg az alapfokozatot, és 1925 júniusában már a mesterfokozatot is. Már ekkor megmutatkozott baloldali politikai elkötelezettsége, és 1924 februárjában ő küldte el La Follette szenátornak - az amerikai progresszivizmus akkori vezérének és 1924. évi elnökjelöltnek - számos diáktársa nevében is azt a levelet, amelyben felajánlotta szolgálatukat választási kampányának támogatására.

Ezután posztgraduális tanulmányokat folytatott a Harvard Egyetemen, majd megkezdte az első világháború előtti évtizedek francia fizetési mérlegéről készített doktori dolgozatának megírását, amelyből kitünik az első világháború előtti helyzethez, az aranydeviza-rendszerhez való vonzódása. 1931-ben szerezte meg doktori fokozatát, dolgozata a Harvard Economic Series sorozatában jelent meg (White [1933]). Fel kellett azonban ismernie, hogy nincs reménye arra, hogy professzori státust szerezzen a Harvardon. Előadói, majd professzori megbízást vállalt a Lawrence College-ban, a wisconsini Appletonban. Közgazdasági nézetei ottani kollégáinak véleménye szerint is ortodox jellegüek voltak.

Jacob Viner adta meg neki a kiemelkedés lehetőséget azzal, hogy 1934-ben meghívta egy három hónapos szakértői munkára a pénzügyminisztériumba. A három hónapból 13 év lett, a Viner részére írt tanulmány csak White hátrahagyott iratai között lelhető föl (White [1934]-et idézi Boughton [2002b] 21. o.). Rövidesen vezető elemző lett a kutatási és statisztikai főosztályon. Elméleti munkáját föladta, csak hivatali munkájával foglalkozott, s nézetei ortodox jellegüek maradtak. Amint ezt Boughton leírja, White mint veszedelmes eszmét elutasította az arany vagy más hatékony horgony nélküli, menedzselt valuta gondolatát, ragaszkodott a monetáris stabilitáshoz, és olyan nemzetközi rendet akart, amely sokkal inkább az adósok, mint a hitelezők megrendszabályozására törekszik (Boughton [2002a], [2002b]). Ez határozta meg a Valutaalap létrehozásával kapcsolatos törekvéseit és Keynesszel való összeütközését is.

White szerepe nem érthető meg Morgenthaué nélkül. White-nak a pénzügyminisztériumba való belépésével gyakorlatilag egyidejüleg nevezte ki Roosevelt az akkor 42 éves mezőgazdasági alapképzettségü barátját, Henry Morgenthaut a Pénzügyminisztériumba ügyvivővé, majd 1934. január 1-i hatállyal miniszterré. New York államban, a Hudson-völgyben volt mindkettőjüknek birtokuk, és már régen szoros barátságot kötöttek. White-nak a pénzügyminisztériumon belüli gyors emelkedése rendkívüli képességei, szorgalma és törtetése mellett (azt mondták róla, hogy emiatt ő volt a leggyülöltebb ember Washingtonban) Morgenthauval kialakult szoros kapcsolatának volt a következménye. Morgenthau Roosevelt elnök barátja és bizalmasa volt, a Roosevelthez legközelebb álló három személy egyike, de nem volt pénzügyi szakértő. Szüksége volt tehát olyan szakmai segítőre, akiben 
teljesen megbízhatott, sőt akire rábízhatta magát, és ezt találta meg White-ban. White ugyanakkor Morgenthauban találta meg azt, aki Roosevelt elnök elé tudta vinni, és el tudta vele fogadtatni elképzeléseit. Roosevelt emellett hajlamos volt arra, hogy átnyúljon a kormányhivatalok vezetőinek feje fölött, érvényesítse elképzeléseit és akaratát. Ennek folytán bizalmasa, Morgenthau egyre nagyobb mértékben terjeszthette ki hatáskörét a külügyek területére, és ezért White szerepköre is egyre inkább kiterjedt erre.

White-nak e széles körü aktivitása mellett még arra is volt ideje és ereje, hogy kapcsolatot alakítson ki a szovjet titkosszolgálattal, és hivatalos iratok tömegét adja át nekik. Ez a szovjet kapcsolat ma meglepőbbnek tünik, mint akkor volt. Abban az időben az angol és amerikai vezető értelmiség körében általános volt a Szovjetunió iránti szimpátia. A cári Oroszország megdöntését minden progresszív gondolkozású ember pozitívan értékelte; az 1929-1933. évi nagy válság fokozta a szovjet kísérlet iránti érdeklődést. A második világháborúban a Szovjetunió fegyvertárs volt, támogatása tehát kötelező lett. Ez a szimpátia különösképpen erös volt az eleve baloldali érzelmủekben, mint amilyen White volt, amint La Follette-hez való csatlakozása is mutatja. A szovjetek nagyon ügyesen használták ki ezt a helyzetet nyugati tudósok tették lehetővé például a szovjet atombomba létrehozását is (vö. Sudoplatov-Sudoplatov [1994/1995]).

White ilyetén tevékenységének két szakasza volt, az egyik Whittaker Chambershez, a másik Elisabeth Bentley-hez kapcsolódik. Mindketten idealisták voltak, mindketten egy jobb és emberibb világ reményében vállalták az együttmüködést a szovjetekkel, és mindketten kijózanodtak: Chambers 1938-ban, Bentley pedig 1945-ben szakított a szovjetekkel. Mindketten emlékiratot adtak ki (Chambers [1952]-t idézi Rees [1973], Bentley [1952]). Chambers, amikor felszámolta szovjet kapcsolatait, felszólította a vele addig együttmüködőket, így White-ot, hogy hagyjanak fel ilyen tevékenységükkel. Adolph Berle külügyi államtitkár-helyettest informálta tevékenységéről 1939. szeptember 2-án, egy héttel a Molotov-Ribbentrop-paktum aláírása és egy nappal Lengyelország megtámadása után. Magas állású partnere nem kívánta meg tőle, hogy nevezze meg a vele együttmüködőket. Bentley viszont az FBI New Haven-i irodájában adta fel magát 1945. augusztus 21-én vagy 22-én, és az FBI már megkívánta tőle a vele együttmüködök személyének felfedését. Ennek folytán White ilyen tevékenységére az 1930-as években nem, hanem csak 1945-ben derült fény.

White már 1938 áprilisáig is küldött Chambershez hivatalos pénzügyminisztériumi dokumentumokat, aki lefényképezte és továbbította őket. Ugyanilyen kapcsolata 1940-ben alakult ki Bentley-vel, és 1943 tavaszára a neki átadott anyagok fantasztikus mennyiségüre nőttek: kéthetenként negyven $35 \mathrm{~mm}$-es filmtekercs készült. Bentley szerint White utolsónak maradt bent hivatalában, amin senki sem csodálkozott. Az akkor elvitt anyagokat éjjel dolgozták fel, és reggel ismét elsőnek volt bent, amin ismét senki sem csodálkozott, és vitte vissza az iratokat. Szerinte White és Laughlin B. Currie voltak azok, akik a Szovjetunió számára kedvező irányban tudták befolyásolni az amerikai döntéseket. Currie, White közvetítésével, rövid ideig a pénzügyminisztériumban volt, majd a Federal Reserve Boardhoz került, és végül Roosevelt adminisztratív munkatársa lett. 


\section{A Keynes-terv első változata ${ }^{3}$}

A Keynes-terv első változata (Keynes [1942b] rendkívül összefogott, tudományos igényü mü, Keynes legjobb írásainak egyike, amelynek lényege a következö. ${ }^{4}$

Nemzetközi szinten is ugyanazt kell létrehozni, mint ami az egyes országokon belül már régen kialakult: nemzetközi bankrendszert, nemzetközi klíringuniót, amely ugyanúgy működik nemzetközi téren, mint ahogy az egyes országok bankrendszere országokon belül (2.). Ennek elsődleges előfeltétele egy olyan nemzetközi pénz megléte, amelyet mindenki elfogad - éppúgy, mint ahogy az egyes országokban mindenki elfogadja a nemzeti valutát (1.). Ennek a nemzetközi pénznek a neve legyen bancor, és a létrehozandó nemzetközi klíringunió tagállamainak központi bankjai ebben vezessék egymás közti elszámolásaikat (1.), de a bancor nem kerülhet forgalomba.

A két alapító állam: az Egyesült Államok és az Egyesült Királyság megállapodik valutájuk kiinduló, bancorban és rajta keresztül aranyban kifejezett értékarányában, és ehhez viszonyítva kell megállapítani a többi tag valutájának kiinduló értékét (17.1.). Ezt követően, elsősorban az egyes országok külkereskedelmi forgalma alapján, kvótákat kell meghatározni; az országok ennek megfelelö összegű hitel felvételére jogosultak, illetve ettől függ szavazataik száma a klíringunióban (17.2.). A klíringunió létrehozásához nincs szükség alaptőke-befizetésre, mert a kedvező mérlegpozíciójú országok többlete szükségképpen annyi, mint a kedvezőtlen pozíciójú országok hiánya, azaz a többletek finanszírozhatják a hiányokat (1.). Az elgondolás egyik központi eleme tehát a nemzetközi pénz, amely nem lehet azonos egyik ország pénzével sem, mert a nemzetközi pénznek más a funkciója, mint bármely ország nemzeti pénzének. Az elgondolás másik központi eleme a folyószámlahitel (overdraft). Minden ország automatikus folyószámlahitel-lehetőséget kapna kvótájának arányában, és a hitelező vagy adós pozícióban lévő országok nem egymással, hanem a klíringunióval lennének kapcsolatban (5.).

Ezt az elgondolást már Keynesnek az indiai valutaproblémák megoldására elöterjesztett javaslatában is fellelhetjük (Keynes [1913]), majd ismét felbukkan a Treatise on Money második kötetében (Keynes [1930]). ${ }^{5}$ A különbség csupán az, hogy a Treatiseban a nemzetek fölötti bank és nemzetek fölötti bankpénz (Supernational Bank és a Supernational Bank Money, röviden SBM) kifejezések szerepelnek, és a Keynes-terv részletesen kifejti, amit a Treatise csak vázlatosan ad elö. Keynes életmüve tehát egységes egész, amelynek betetőzése az itt bemutatott, de alig ismert elgondolás a nemzetközi pénzügyi és gazdasági rendröl.

Ez a tervezet detronizálta volna az aranyat, tehát alapvetően új rendszert hozott volna létre, mert a bancor, a nemzetközi elszámolási pénz lépett volna az arany helyébe. Keynes a tervvel szembeni - elsősorban amerikai - ellenállás csökkentésére mégis úgy fogalmaz, hogy „az arany szerepe lényegében véve változatlan

\footnotetext{
${ }^{3}$ Rövidítve lásd a tanulmány elektronikusan közölt Mellékletének A Keynes-terv első változata [Javaslatok egy nemzetközi valuta (vagy klíring-) unióra, 1942. február 11.] című M1. szemelvényében.

${ }^{4}$ A zárójelbe tett sorszámok a Keynes-terv megfelelő pontjait jelölik.

${ }^{5}$ Mindkét írást Szakolczai [2016] ismerteti.
} 
maradna”. Ez annyiban igaz, hogy a bancor értékét aranyban definiálnák (38.), és fennmaradna az aranyátutalások lehetősége. A rendszer tartós fennmaradásának Keynes szerint két előfeltétele van. A bancor értéke aranyban rögzített, de nem megváltoztathatatlanul (43.), és a központi bankok nem kérhetnek aranyat a klíringuniótól bancorkövetelésük ellenében (41.). (Mindez jól mutatja Keynes elörelátását.) Keynes nem tudta elfogadtatni ezt a két alapelvet. Két és fél évtized múlva az arany szabadpiaci ára megnőtt, hivatalos ára azonban változatlan maradt, a tagállamok dollártartalékuk egy részért aranyra kívánták beváltani az amerikai pénzügyminisztériumnál a piaci ár alatti, rögzített áron, és 1971-ben a Bretton Woods-i rendszer összeomlott.

Alapvetően új az árfolyamra vonatkozó javaslat is. A nemzetközi gyakorlat két rendszert ismer: a rögzített és a lebegő árfolyamokét. A rögzített rendszerben a valuták egymás közti árának megváltoztatására általában csak nagy késéssel kerül sor, sokkal azután, hogy ennek szükségessége fölmerül, sőt általában súlyosan válságos körülmények között, sokaknak nagy veszteséget okozva. A lebegő árfolyamrendszerben az árfolyamok napról napra (sőt az utóbbi évtizedekben már percről percre) változnak a piaci erők hatására; a rendszerben tehát nincs fix horgony. Ez nyilván problematikussá tesz minden gazdasági kalkulációt. Emellett csak a piaci fundamentalizmus eltökélt hívei gondolják (szerintem tévesen), hogy a piaci erök szabad játéka optimális helyzethez vezet. Elöször Keynes mutatott rá arra, hogy a piacokon a csordaszellem, helyesebben az állati ösztönök (animal spirits) hatása érvényesül, és ez a valuták értékarányainak a fundamentumok által nem indokolt, sokszor extrém mértékü ingadozásához vezet. A mai keynesiánusok (például Akerlof-Shiller [2009]) még nagyobb nyomatékkal hangoztatják ugyanezt.

Ha a rögzített (de megváltozatható) valutaárfolyamok nem vezetnek általános egyensúlyra, vagyis minden ország fizetési mérlegének hozzávetőleges egyensúlyára, akkor a nemzetközi klíringunió beavatkozására van szükség. E beavatkozás célja „expanziós nyomás létrehozása a világkereskedelemben a jelenlegi kontrakciós helyett" (4.), alapelve pedig, hogy az egyensúlyzavarért a többletországok éppúgy felelősek, mint a hiányországok. Ezért a korrekció terhe nem hárítható egyedül a hiányországokra és ezek restrikciós politikájára, hanem szükség van a többletországok expanzív szellemü politikájára is (16). Nem a jelenlegi gyakorlat tehát az egyedüli megoldás, vagyis az, hogy a hiányországok csökkentsék a belföldi vásárlóerőt és keresletet. Ez nyilvánvalóan az Általános elmélet szelleme!

Az első javasolt lépés, amint erről már volt szó, hogy a klíringunió a folyószámlahitel lehetőségének megnyitásával és a többletországok szufficitjének felhasználásával nyújtson hitelt a hiányországoknak. E javaslat alapváltozatában az a leginkább forradalmi, hogy az adós országok ne fizessenek kamatot a hitelező országoknak, hanem csupán 1-2 százalékos illetéket a klíringuniónak, és a hitelező országok se kapjanak kamatot, hanem ők is ugyanezt az 1-2 százalékos illetéket fizessék a klíringuniónak (17), mert ők éppúgy felelősek az egyensúlyzavarért, mint az adós országok. Keynes látta, hogy ezt aligha lehet elfogadtatni a hitelező országokkal, és ezért leírta, hogy ez az illetékrendszer nem feltétlenül szükséges, de elvben ez az optimális. 
Ha a hitelnyújtás nem hoz megoldást, a második javasolt lépés a leértékelés (18-4.a, 4.b), és a klíringunió szerepe a leértékelési versenynek a megakadályozása úgy, hogy leértékeléshez csak valóban indokolt esetben lehessen folyamodni. Szerepel még a felértékelés javaslása azoknak az országoknak, amelyek exporttöbblete az egyensúlyzavar oka.

Ha ez sem hoz megoldást, a hiányországoknak harmadik lépésként joguk van importjuk korlátozására, valamint a belföldi felhasználást szolgáló termelésük védelmére és támogatására, exportjuk támogatására azonban nem $(19,21)$. A klíringunió szerepe itt a belső piac indokolatlan védelmének és az importkorlátozási versenynek a megakadályozása. E felfogás szerint tehát a nemzetközi kereskedelem szabadságának növelése nem egyirányú utca, ahol a már megadott kedvezmények nem vonhatók vissza, mint ma. Ha valamely ország nem képes másként elérni a teljes foglalkoztatást és a gazdaság növekedését, akkor kereskedelempolitikai eszközökhöz is folyamodhat.

A negyedik lépés a konjunktúrapolitika. A többletországoknak ki kell terjeszteniük a belföldi keresletet, és ha fizetésimérleg-többletük ezután is fennmarad, a többletet az elmaradott országok fejlesztését szolgáló hitelek nyújtására kell fordítaniuk (18-5.a). A klíringunió feladata nyilván az, hogy ezt a politikát javasolja a többletországoknak.

Keynes ezeknek az eszközöknek a tárgyalása után foglalkozik a tőkeforgalom ellenőrzésével. Ebben a javaslatában még azt az álláspontot képviselte, hogy az lenne a helyes, ha „a tőkeforgalmat mindkét végén ellenőriznék” (45.), ezt az álláspontját azonban később feladta, egyrészt mint megvalósíthatatlant, másrészt úgy vélve, hogy elképzelései e nélkül is megvalósíthatók. Javaslatainak tartós eleme maradt azonban az az álláspontja, hogy meg kell különböztetni „a lebegő tőke [vagyis a forró pénz] mozgását a világ erőforrásainak kifejlesztését szolgáló valódi új beruházástól”, illetve „,azokat a tőkemozgásokat, amelyek előmozdítják az egyensúly helyreállítását, tehát amelyek a többletországokból a hiányországokba irányulnak, illetve azokat a spekulatív tőkemozgásokat vagy tőkemeneküléseket, amelyek a hiányországokból a többletországokba irányulnak (46.). Mindvégig fenntartotta azt az álláspontját is, hogy „nincs olyan ország, amely a jövőben minden további nélkül megengedheti a tőkemenekülést politikai okokból vagy a belföldi adózás elkerülése céljából”, és ugyanez vonatkozik a menekülö és spekulatív tőke befogadására is (47.).

Keynes végül leírja, hogy „[h]a valóban hiányzik a termelő kapacitásunk ahhoz, hogy fenntartsuk életszintünket, akkor ennek a szintnek a leszállítása elkerülhetetlen" (12.). Nem volt tehát a felelőtlen költekezés híve, és nem feltételezte, hogy a fogyasztás hitelböl való kiterjesztése járható út, mint ahogy ezzel mindmáig megvádolják.

Az itt leírtak azt jelentik, hogy Keynes vissza akarta állítani a nemzeti gazdaságpolitika összes eszközét, tehát a monetáris és költségvetési politika mellett az árfolyam-politikát és a kereskedelempolitikát is, amennyiben ezekre valóban és nélkülözhetetlenül szükség van, és amennyiben ezek nem sértik más országok és az egész nemzetközi közösség érdekeit. Emellett nagyon határozottan hangsúlyozta, hogy 
saját ügyeikben intézkedési joguk csak az egyes országoknak lehet. Bizonyos határokon belül teljesen szabadon intézkedhetnek, ezen a határon túl csak a klíringunióval lebonyolított tanácskozás után és a klíringunióval egyetértésben. A klíringunió tehát korlátozhatja a szuverenitást azzal, hogy nem járul hozzá ahhoz, amit a tagállamok tenni akarnak, ha ez nem indokolt, de nem írhatja elő a tagállamoknak, hogy mit tegyenek. A mai terminológia szerint tehát a nemzetek együttmüködésének volt a híve, és nem a nemzetek fölé rendelt szupranacionális hivatalnak. Meggyőződésem szerint ma is ez a helyes szemlélet.

Áttérve e javaslatok elméleti hátterére, Keynes már akkor felismerte a MundellFleming-modell legfontosabb elemeit, amely modellért Mundell 1999-ben Nobel-díjat kapott, sőt ezt állította elemzésének és javaslatainak központjába. Amint ez köztudott, a nyílt gazdaság trilemmája azt jelenti, hogy nyitott és föként kis, nyitott gazdaságban nem lehet egyszerre szabad tőkeforgalom, független makroökonómiai politika és rögzített valutaárfolyam (Mundell [1963], Fleming [1962]). Ez a trilemma nyilván dilemmára egyszerüsíthető le: egy ország gazdaságpolitikája vagy a teljes foglalkoztatás, jólét és gazdasági növekedés szempontjainak, vagy pedig az árfolyam és a nemzetközi egyensúly szempontjainak adhat elsőbbséget.

A mai gazdaságelméleti főirány és a mai általános gazdaságpolitikai gyakorlat ennek a dilemmának azt az oldalát ragadja meg, hogy minden országnak fenn kell tartania a szabad tőkeforgalmat, az euróövezethez tartozó országoknak pedig még a rögzített valutaárfolyamot is, akár a teljes foglalkoztatást, a közjólétet és a gazdasági fejlődést szolgáló független makroökonómiai politika kárára is. Keynes ennek a dilemmának a másik oldalát ragadta meg: azt, hogy a nemzeti gazdaságpolitika az elsődleges, vagy legalábbis nem hagyható figyelmen kívül. Ha szükséges, javára korlátozni kell a szabad tökeforgalmat, és engedményeket kell tenni a nemzetközi kereskedelmi forgalom teljes szabadságának kárára, de csak a szükséges mértékben, és csak úgy, hogy ez ne okozzon kárt más országoknak. Ez szükségessé teszi egy nemzetközi szervezet, a klíringunió létrehozását.

Ha azonban Keynes már akkor fölismerte a Mundell-Fleming-modell legfontosabb elemeit és szemléletmódját, akkor fel kellett ismernie North [2005] szemléletmódját is. Felmerül ugyanis a kérdés, hogy miért lehet szükség az előbb tárgyalt intézkedésekre és felmentő záradékokra. Egyrészt azért, mert az egyes országok és vezetőik hibát követhetnek el, és Keynes - amint erre Skidelsky határozottan rámutat - megértő volt ezzel szemben, mert tudta, hogy "tévedni emberi dolog” (Skidelsky [2000] 476. o.). Másrészt North terminológiája szerint nem ergodikus világban élünk, ahol napról napra teljességgel elöreláthatatlan események következhetnek be, amelyek nagy, sőt alapvető mértékben változtathatják meg és ronthatják le egyes országok helyzetét úgy, hogy ezért őket semmiféle felelösség sem terheli. Ezért minden emberi berendezkedésnek irgalmasnak kell lennie, és elengedhetetlenek azok a felmentő záradékok, amelyek lehetővé teszik az országok és vezetőik számára, hogy nagyobb veszteség és megrázkódtatás nélkül korrigálják hibáikat, illetve alkalmazkodjanak az előre nem látott új helyzethez. Ez talán Keynes legfontosabb tanítása és egyben a közgazdasági elmélet későbbi fejlödésének elörevételezése. 


\section{A White-terv első változata ${ }^{6}$}

Míg a Keynes-terv kiérlelt, tudományos igényü, gondosan szerkesztett, egységes egész, 16 oldalon, a White-terv 45 oldalán látszik, hogy sietve készült, különböző anyagok egybeszerkesztésével. Tartalmi szempontból is teljes ellentéte a Keynes-tervnek. Ez döntő részben a Mundell-háromszöggel kapcsolatban leírtakra vezethető vissza. Míg a Keynesterv az Általános elmélet szellemében, a dilemmának azt az oldalát ragadja meg, hogy a közjót szolgáló nemzeti gazdaságpolitikának kell elsőbbséget adni, a White-terv a dilemmának azt az oldalát tekinti, hogy a klasszikus és neoklasszikus elvek szerinti nemzetközi rendnek van elsőbbsége a nemzeti gazdaságpolitikával szemben.

A White-terv az I. rész A1. és B1. pontjában azzal indít, hogy a Valutaalap elsődleges célja „az Egyesült Nemzetek valutaárfolyamainak stabilizálása”, ugyanis „nyilvánvalók a stabil valutaárfolyamok elérésének előnyei”. Ezt hasonló szellemű célok követik, és fel sem merül az a gondolat, hogy a rögzített valutaárfolyamokhoz való ragaszkodás károkat okozhat egyes országoknak, sőt a nemzetközi közösség egészének. A célok között szerepel „a valutaforgalom ellenőrzése szükségességének és alkalmazásának csökkentése", ellentétben a Keynes-tervvel, amely szükségesnek tartotta a valutaforgalom ellenörzésének fenntartását.

A II. rész A1. pontja szerint az Alap „vásárol, elad vagy tart aranyat, valutákat, külföldi fizetőeszközöket, váltókat, valamint a »tag«-államok államkötvényeit, és a pénzeszközök, mérlegek, csekkek, váltók és elfogadványok nemzetközi forgalmának klíringházaként müködik”. Ennek megfelelően a IV. rész A1. pontja kimondja, hogy „,az Alap aranyból, a tagállamok valutáiból és a tagállamok államkötvényeiből áll, olyan összegekben, ahogy ezt a megállapodásban szereplő formula elöírja. Az összes jegyzés [...] legalább 5 milliárd dollár lesz. [...]”. A keynesi elgondolással szemben tehát, amely kimondja, hogy a többletországok követel egyenlegeinek összege szükségképpen egyenlő a hiányországok tartozik egyenlegeinek összegével, ezért a hiány a többletekkel fedezhető, és nincs szükség befizetésekre, itt határozottan fellép az alaptőke-befizetés igénye.

Az ellentétek tovább nőnek a III. résszel. Keynes azt írja terve 55. pontjában, hogy „rendszerünknek olyannak kell lennie, hogy képes legyen széles, sőt általános bővülésre", vagyis elfogadhatónak kell lennie minden ország számára, társadalmi berendezkedésétől függetlenül, továbbá „,külön meggondolást igényelne Oroszország pozíciója, amely harmadik alapító tag lehetne". A White-terv e fejezete ezzel szemben pontokba szedve sorolja fel az amerikai stílusú gazdasági berendezkedés legfontosabb alapelveit, amelyek elfogadása „a tagság elnyerésének feltétele”. E fejezet utolsó, $B$ 9. pontja leszögezi ugyan, hogy „a tagságot nem szabad korlátozni a bármely ország által alkalmazott sajátos struktúra alapján”, és „Oroszország kizárása mérhetetlenül nagy hiba lenne", de ez mintha ellentétben lenne e fejezet elöbbi részével, és mintha a kondicionalitás gyakorlatának baljós árnyékát vetítené elöre.

Az ellentét tovább fokozódik a IV. résszel. A Keynes-terv nem foglalkozik a hatalmi kérdésekkel, a White-terv e fejezete viszont olyan megoldást javasolt, amely

\footnotetext{
${ }^{6}$ Rövidítve lásd a tanulmány elektronikusan közölt Mellékletének A White-terv első változata címü M2. szemelvényében.
} 
a szavazatok kereken 60 százalékát adta volna az Egyesült Államoknak és Latin-Amerikának, és alig 2,86 százalékát a Szovjetuniónak, amit sohasem fogadhattak volna el sem az európaiak, sem pedig a Szovjetunió.

Az ellentét az V. részben kulminál. E fejezet az „Egy új nemzetközi valuta” címet viseli, és valóságos gúnyirat a Keynes-tervvel szemben. Azt írja, nevetségessé téve a bancor gondolatát, hogy „már most van [...] egy nemzetközi csereeszközünk, mégpedig az arany. [...] Nincs [tehát] semmi előnye annak, hogy a meglévő aranyat a nemzetközi pénzforgalom új eszközével helyettesítsük. [...] Egy »kereskedelmi dollár« vagy »demos" vagy "victor« vagy »amit-csak-akarsz« valutáris egység az Egyesült Államok dollárja helyett, akár ugyanazzal, akár attól eltérő értékkel, nem segítené jobban a külkereskedelmet, mint egy új zászló elfogadása." Ez bizony a később megvalósított, majd csúfosan megbukott arany-dollár standard baljós árnyékának elörevetítése ennek összes következményével együtt.

Hogy miként lett ebből a két, ennyire ellentétes elgondolásból mindkét fél és mások által is elfogadott közös megoldás, azzal a továbbiakban foglalkozunk.

\section{A Keynes-terv második változata, a „fehér könyv”7}

A Keynes-terv második változata 1943 áprilisában készült, míg az első változat Horsefieldnél 1942. február 11-i dátummal szerepel. Ezt a tizennégy hónapot az magyarázza, hogy Keynes és az angolok csak ekkor tudták elérni az érdemi tárgyalás megkezdését az amerikaiakkal. ${ }^{8}$

A fehér könyv nagyrészt az előző változatban foglaltak megismétlése, de ha lehet, még radikálisabb, mint a Keynes-terv első változata. Legradikálisabb eleme a bevezetése, amely valósággal a függő és kiszolgáltatott helyzetben lévő kis országok függetlenségi nyilatkozata.

„A háború után felállítandó nemzetközi gazdasági rendszer alapjainak teljesíteniük kell [az alábbi feltételeket] ahhoz, hogy tartósak legyenek:"

a) „A lehetö legkevésbé szabad csak beavatkozni a belső nemzeti politikákba, és a tervnek nem szabad letérnie a nemzetközi területről. [...] A[z egyes országok] belföldi politik[áj]a terén a javasolt intézmény kormányzótanácsa hatáskörének az ajánlásokra kell korlátozódnia vagy legföljebb az intézmény által nyújtott új lehetőségek nagyobb mértékủ igénybevételével kapcsolatos feltételek megszabására."

b) „A terv technikájának alkalmazhatónak kell lennie [mindenütt], függetlenül a leendö tagállamok típusától, kormányzati elveitől és gazdaságpolitikájától."

c) „Az intézmény vezetésének őszintén nemzetközinek kell lennie, anélkül, hogy túlsúlyos hatalma, vagy vétójoga, vagy kényszerítő ereje lenne bármely országnak vagy csoportnak, és meg kell őrizni a kisebb országok jogait és privilégiumait.”

\footnotetext{
${ }^{7}$ Rövidítve lásd a tanulmány elektronikusan közölt Mellékletének A Keynes-terv második változata (rövidítve) (Javaslat egy nemzetközi klíringunióra, 1943. április) című M3. szemelvényében.

${ }^{8}$ E terv előkészítő változata is elérhető Keynes írásai között (Keynes [1942c]), kelte 1942. augusztus 28.
} 
d) „A nemzetek közötti minden megállapodástól vagy szerződéstől megkívántatik, hogy olyan fenntartásokat tartalmazzon, amely megadja a jogot arra, hogy [mindegyik szerződő állam bizonyos körben] tetszése szerint cselekedjen. Annak érdekében, hogy ezek a megállapodások teljesen önkéntesek legyenek, amíg fennállnak, és lezárhatók legyenek, ha terhessé váltak, lehetővé kell tenni a kötelezettségek felmondását megfelelő előzetes bejelentés után. Ha sok tagállam élne ezzel a lehetőséggel, a terv összeomlana. De ha [a tagállamok] szabadon megszabadulhatnak ennek rendelkezéseitől, ha ez szükséges lenne, inkább lesznek hajlandók arra, hogy elfogadják."

e) „A tervnek nemcsak az általános érdekeket kell szolgálnia, hanem az összes résztvevő egyéni érdekeit is, és nem szabad különleges gazdasági vagy pénzügyi áldozatokat kívánnia egyes államoktól. Egyetlen résztvevőtől sem szabad kérni, hogy tegyen vagy felajánljon bármit, ami nem áll a saját valóságos hosszú távú érdekében."

Ezt a bevezetést Keynes feltehetően az utolsó pillanatban tette be a már kész szöveg elé, mert bekezdéseinek még csak számozása sincs. Ennek megírására a White-tervnek azok az elemei provokálhatták Keynest, amelyek fokozták ezeknek az országoknak a kiszolgáltatottságát. Sajnos nem sikerült áttenni ezt a szemléletet a Valutaalap gyakorlatába, ami joggal minősíthető tragikusnak, mert a Valutaalap gyakorlata példaként szolgált más nemzetközi szervezet számára is. Az egyenjogú országok önkéntes együttmüködésének helyébe a függő és kiszolgáltatott helyzetben lévő kis országok irányítása, megrendszabályozása vagy akár megbüntetése lépett.

A továbbiak ismertetése és kommentálása rövid lehet, mert Keynes semmit sem változtatott mondanivalója lényegén, hanem, ha lehet, még hajthatatlanabb módon adta elö ugyanazt.

Az I. fejezet leszögezi, hogy az egyensúlytól való eltérésért éppúgy felelös a hitelezö, mint az adós, és hogy szükség van a bizalom olyan légkörére, amely lehetővé teszi, hogy azok az országok, amelyek kellö bölcsességgel viszik saját ügyeiket, ne legyenek kénytelenek, romboló külső erők hatására, a restrikció és a diszkrimináció eszközeihez folyamodni. Ennek megfelelően a II. fejezetben újra megjelenik az a javaslat, hogy a kvóták egy bizonyos hányadának akár tartozik, akár követel irányban való túllépése esetén illetéket kell fizetni a klíringuniónak, és hogy az egyensúly helyreállítása intézkedéseket kíván meg mind a tartozik, mind a követel egyenlegű országok részéröl. A III. fejezetben megjelenik egy új és nagyon radikális javaslat, amely valóságos hadüzenet a White-tervnek vagy akár az Egyesült Államoknak. E szerint, ha valamely ország többlete meghaladna egy bizonyos mértéket, ennek „a többletnek az esetleges végső törlése vagy kötelező beruházása lenne a megfelelő intézkedés" (Horsefield [1969b] 25. o., kiemelés tőlem - Sz. Gy.).

A IV. fejezet megismétli, hogy „a terv arra törekszik, hogy kontrakciós helyett expanziós nyomást gyakoroljon a világkereskedelemre” (uo. 26. o.), „a kontrakciós nyomás [következménye ugyanis] a társadalmi rend megzavarodása és a modern világunk jogos reményeinek meghiúsulása”. Az V. fejezet helyesli a tőkeforgalom ellenőrzését, a tőkekiviteli és tőkebehozatali oldalon egyaránt, ami azonban nem a klíringunió, hanem az egyes országok feladata lenne, saját intézményeik útján. $\mathrm{Ez}$ is hadüzenet, még ennél is súlyosabb hadüzenet azonban a következő: a klíringunión belül fennmaradhatnának az egyes országok közti, földrajzi és történeti 
okokon alapuló különleges kapcsolatok, így „egy sterlingövezet és egy dollárövezet csoportja" (uo. 30. o.). Ha viszont van sterlingövezet, és van dollárövezet, akkor mi sem természetesebb, mint hogy a klíringuniónak két adminisztratív központja legyen, az egyik New Yorkban, a másik pedig Londonban. Nem kevésbé természetes, hogy a legfelsőbb szerv, az igazgatótanács üléseit - az arányosság és a párhuzamosság követelményeinek megfelelően - felváltva tartsák Amerikában és Angliában. A hadüzenetek immár meglehetős hosszú sorában talán ez a legfontosabb. Az amerikaiak egy egységes világot akartak, amelyhez csak a Szovjetunió nem tartozott volna. Nem akartak sterlingövezetet és dollárövezetet, hanem egységes világot, vagyis dollárövezetet az egész világon, amint ezt a White-terv ki is mondta, sőt amint ebben később, Bretton Woodsban meg is állapodtak. Ennek megfelelően nem óhajtottak két adminisztratív központot sem, hanem csak egyet, természetesen Amerikában.

A hadüzenet az arannyal foglalkozó VI. fejezetben folytatódik. A bevezető félmondat szerint: „Az aranynak még mindig nagy a pszichológiai értéke” (uo. 30. o., kiemelés tőlem - $S z$. $G y$.), éles ellentétben az amerikai állásponttal, amely szerint a nemzetközi pénzrendszert az arany reális értékére kell felépíteni. Keynes természetesen megtette a szükséges engedményeket az aranydeviza-rendszer híveinek, de ott van ennek a pontnak a szövegében is a már idézett két kritikus mondat: „Egyetlen tagállam sem lenne jogosult arra, hogy aranyat kérjen a klíringuniótól bancoregyenlege fejében”, illetve: „a bancor aranyban kifejezett értéke rögzített lenne, de nem megváltoztathatatlanul”. És végül egy látnok szava: „Semmi célt sem szolgálnánk azzal, ha megpróbálnánk tovább fürkészni a jövőt, vagy megjósolni, hogy végül mi fog történni." (Uo.) Most már nagyon jól tudjuk, hogy mi történt, és hogy ami történt, pontosan megfelelt Keynes itt ki nem mondott várakozásainak.

A hadüzenet folytatása a VII. fejezet, amely a tőkeforgalom ellenőrzésének fenntartása mellett érvel. „Nincs olyan ország, amely a jövőben minden kockázat nélkül megengedheti a tőkemenekülést politikai okokból vagy a belföldi adózás elkerülése céljából [...]. Ezen okok miatt széles körü az egyetértés abban, hogy a tőkeforgalom ellenőrzésének, a beáramlóénak és a kiáramlóénak egyaránt, a háború utáni rendszer tartós elemének kell lennie" (uo. 31. o., kiemelések tőlem - Sz. Gy.). A klíringunió és a kereskedelmi politika kapcsolatával foglalkozó VIII. fejezet megismétli, hogy „[h]a a szerződő államok egyikének kvótája egy bizonyos hányadát meghaladó tartozik egyenlege lenne [...], importkorlátozáshoz vagy cserekereskedelmi megállapodáshoz vagy olyan típusú magasabb importvámokhoz folyamodhatna, amilyeneket a szerzödés normális körülmények között nem enged meg" (uo. 33. o.).

A XI. fejezet, a végkövetkeztetés mintegy ellensúlyozza a bevezetést. Azt írja, hogy a terv „az unió tagjaitól szuverén jogaik nagyobb mértékủ feladását kívánja, mint amekkorát szívesen megadnának”, és hogy „,a háború után világban nagyobb készségre lesz szükség a nemzetek fölötti rendelkezések elfogadására, mint korábban" (uo.). Megítélésem szerint azonban nincs ellentét a bevezetés és a végkövetkeztetés között: szükség van a nemzetek fölötti rendre, de ez nem sértheti senkinek, különösképpen nem a gyöngébbeknek, kisebbeknek és kiszolgáltatottaknak az érdekeit, jogait vagy akár privilégiumait. 


\section{A White-terv második változata ${ }^{9}$}

E terv első változata (White [1942]) 46 oldal volt, ez pedig alig 14 oldal, tehát alaposan átdolgozott, tömör szöveg. A szöveg új ugyan, de a koncepció nem: White, akárcsak Keynes, nem változtatott javaslata lényegén, hanem legfeljebb csekély engedményeket tett.

$\mathrm{Az}$ I. fejezet szerint az Alap elsődleges célja ugyanaz, mint az első változatban: „A valutaárfolyamok stabilizálásának előmozdítása”, és ehhez az alapvető célhoz igazodik a többi cél is. A II. fejezet szerint az alap összetételét illetően sincs változás: "Az Alap a tagállamok kormányainak aranyából, valutáiból és értékpapírjaiból áll”, a kvóta pedig a befizetési kötelezettségként aláírt összeg, amely összesen legalább 5 milliárd dollár. A III. fejezet szerint az Alap pénzügyi egysége másnak látszik, de ugyanaz: „Az Alap pénzügyi egységének az unitasnak kell lennie, amelynek értéke 137 1/7 szemer (1 szemer = 0,0648 gramm) arany (10 dollár egyenértéke). Az unitas értékének semmiféle megváltoztatása sem lehetséges a tagállamok szavazatai 85\%ának jóváhagyása nélkül." Ez nem jelent mást, mint hogy nem 1, hanem 10 dollárban kell számolni, ami azonban semmiféle elmozdulást sem jelent az e terv előző változatában is szereplő arany-dollár-standardtól. Az unitas aranyban kifejezett értékének megváltoztatása elvben lehetséges ugyan, de csak az Egyesült Államok beleegyezésével, amelynek megszerzése azonban valószínủtlen. Megmarad emellett a kétoldalú konvertibilitás is, ami később a Bretton Woods-i rendszer összeomlását okozta. A IV. fejezet a valutaárfolyamokkal foglalkozik, és azt mondja ki, hogy ezek megállapítása során az egyes valuták 1943. július 1-én dollárban kifejezett értékéből kell kiindulni, noha ettől indokolt esetben el lehet térni. Egy múltbeli dátum ilyen kiemelésének helyessége természetesen vitatható.

A hatáskörökkel és eljárásokkal foglalkozó V. fejezet szerint az Alap vásárol, elad és tart aranyat, valutákat és a tagállamok kormányzati értékpapírjait és így tovább, ami ismét kereskedelmi tevékenység a többletek és a hiányok automatikus kiegyenlítödése helyett. A terv emellett a hiányvaluták (scarce currencies) adminisztratív jellegü elosztását irányozza elő. Az igazgatással foglalkozó VI. fejezet fenntartja az Egyesült Államok és Latin-Amerika domináns szerepét. Végül a tagországok magatartását tárgyaló VII. fejezet tizenegy oldalról egyetlen oldalra rövidült ugyan, de ebben az egyetlen oldalban benne van a nemzetközi kereskedelmi és tökeforgalom teljes szabadsága, valamint az Alap ajánlásainak elfogadása melletti kötelezettségvállalás, a keynesi tervben szereplő fenntartásoknak szóló némi engedményekkel.

Ez az elkerülhetetlenül rövidre fogott és a részleteket mellöző összeállítás, különösképpen a Keynes-terv 2. változatával egybevetve, azt mutatja tehát, hogy ebben az időben a süketek párbeszéde folyt. Keynes nagyon határozottan megkeményítette álláspontját, és némi formális változtatások ellenére White sem változtatott javaslatainak lényegén. Mindkét fél megállapodásra volt azonban ítélve: a háború végére ki

\footnotetext{
${ }^{9}$ Rövidítve lásd a tanulmány elektronikusan közölt Mellékletének A White-terv második változata (Előzetes vázlatos áttekintés az Egyesült és Társult Nemzetek Nemzetközi Stabilizációs Alapjára vonatkozó javaslatról, 1943. július 10.) című M4. szemelvényében.
} 
kellett alakítani a háború utáni nemzetközi pénzügyi rendszer alapelveit, ezért előbbutóbb el kellett jutni valamiféle megoldásra, és ezt a végső egyeztetést indította el a következő részben tárgyalandó közös nyilatkozat.

\section{A közös nyilatkozat ${ }^{10}$}

A „süketek párbeszéde” után elkerülhetetlen volt a végső egyeztetés. Az ezzel kapcsolatos tárgyalásokat Keynes és White bonyolította ugyan le, de az ennek eredményeként létrejött közös nyilatkozatot már nem ők írták alá, hanem brit kormányzati anyagként, fehér könyvként jelent meg mint szakértők véleménye, a szakértők megnevezése nélkül.

A lényeg az, hogy Keynesnek és az angol szakértőknek fel kellett adniuk a klíringuniót, és el kellett fogadniuk a stabilizációs alap tervét. Fel kellett adniuk a bancort, és el kellett fogadniuk az arany-dollár-standardot. Végül fel kellett adniuk a jegyzett tőke nélküli és az automatikus hitelre (overdraftra) felépülö rendszert, és el kellett fogadniuk a jegyzett tőkére fölépülő rendszert. Ha angol részről nem Keynes vezeti a tárgyalást, és nem az ő kipróbált barátai a partnerei, akkor ez teljes és tökéletes vereség, ez azonban mégsem lett az. Keynes, megtéve ezeket az alapvető engedményeket, amelyek nyilván mérhetetlenül fájdalmasak voltak számára, hosszú és szívós utóvédharcot folytatott mindannak a megörzéséért, ami megörizhető volt. Végül, ami szinte hihetetlen, kivívta, hogy a közös nyilatkozat deklarálta az ő céljait, megörizte elveit, és az előbb leírt alapvető engedményeket valósággal a technikai szintű módosítások szintjére szállította le. Ebből a tárgyalási és szövegezési szintű győzelemből mégsem lett igazi győzelem. Ennek a megállapodásnak a talaján el lehetett volna érni mindazt, amit Keynes el akart érni, ahhoz azonban egy Keynes kellett volna nemcsak ennek a közös nyilatkozatnak az elfogadásakor, hanem a Valutaalap müködésének legalább az első éveiben. Keynes azonban akkor már nem élt, elképzelései nem valósulhattak meg nélküle, és a Valutaalap eredeti koncepciója összeomlott.

Áttérve a közös nyilatkozat szövegének elemzésére, már a bevezetés utolsó mondata, amelyben az aktív foglalkoztatás, az észszerű mértékủ árstabilitás és a valutaárfolyamok rendezett korrekciója szerepel, egyértelmüen keynesi jellegü, mert csak az észszerü mértékü árstabilitást tekinti célnak, és megengedi a valutaárfolyamok rendezett korrekcióját.

A magyarázó jegyzetek 1. és 2. pontja tartalmazza Keynes és az angolok leglényegesebb engedményeit, amelyekről már volt szó. Az 5. pont szerint „az Alaptól [...] megkívántatik [...], hogy jóváhagyjon minden olyan változást, amelyre szükség van az alapvetö egyensúlyzavarok korrekciójához, és [...] a helyzet meghatározó tényeként kell elfogadnia, és nem szabad kritizálnia a helyzet megváltoztatását kérő ország belföldi, társadalmi vagy politikai célkitüzéseit". Ez a tagországok törekvéseit az Alap elgondolásai fölé helyezi, éles ellentétben a White-terv mindkét változatával. Ugyanennek a szellemnek

${ }^{10}$ Az 1944 áprilisában kelt közös nyilatkozat rövidített szövegét a tanulmány elektronikusan közölt Mellékletének M5. szemelvénye közli. A teljes szöveg is elérhető: Joint Statement [1944a]. 
felel meg, hogy „a tagállamok [...] jogosultak arra, hogy bizonyos mértékủ egyoldalú változásokat vezessenek be”, illetve hogy „büntetés nélkül” visszavonuljanak a tagságtól. A 7. pont szerint a „szabad konvertibilitás csak a jellegükben folyó elszámolásnak [minősülö] tranzakciókra vonatkozik, [és] nem vonatkozik a tőkeátutalásokra. A javaslat tehát megengedi a valutaforgalom ellenőrzését, [sőt] akár megkívánhatja a tagoktól bizonyos fajta ellenőrzés gyakorlását.” A 9. pont fenntartja a legfontosabb keynesi tételt: azt, hogy a hitelező országok „éppúgy vállaljanak részt a nemzetközi fizetések egyensúlyának racionális mértékü fenntartásában”, mint az adós országok.

A közös nyilatkozat I. fejezete szerint a Nemzetközi Valutaalap elsődleges célja „a nemzetközi kereskedelem kiegyensúlyozott növekedésének megkönnyítése", továbbá az, hogy „,a tagoknak időt adjanak fizetésimérleg-zavaraik korrekciójára anélkül, hogy olyan intézkedésekhez kellene folyamodniuk, amelyek a nemzeti és nemzetközi prosperitás szempontjából rombolók”, és csak ezt követi „a valutaárfolyamok stabilitásának elömozdítása". A II. fejezet szerint az összes tőkejegyzés mintegy 10 milliárd dollár lesz, ami kétszerese az amerikai részről eredetileg javasolt összegnek. A III. fejezet értelmében „a tag jogosult arra, hogy megvásárolja az Alaptól egy másik tag valutáját saját valutájaért", vagyis e jogának gyakorlása nem igényli senkinek a hozzájárulását. A IV. fejezet kimondja, hogy „az Alap semmilyen mértékben sem változtathatja meg a tag valutaárfolyamát az ország hozzájárulása nélkül”, továbbá hogy „az Alapnak hozzá kell járulnia a tag valutaárfolyamának [a tag által] igényelt megváltoztatásához, ha ez lényeges feltétele az alapvető egyensúlyzavar korrigálásának”. Továbbá „az Alap különösképpen nem utasíthatja vissza a kért változtatást, ha ez az ezt igénylö ország belföldi társadalmi és politikai törekvéseinek megfelelő egyensúly helyreállításához szükséges". Ez azt jelenti, hogy az árfolyam-politika a tagállamok hatáskörében marad mindaddig, amíg ez nem sérti a többi tagállam érdekeit, és nincs ellentétben a világgazdaság egészének stabilitásával. Végül e fejezet szerint „az összes tagállam valutájának aranyban kifejezett értéke egységesen megváltoztatható, ha ehhez minden olyan ország hozzájárul, amelynek kvótája meghaladja az összes kvóta 10 százalékát", vagyis a vezető államok hozzájárulásával megváltoztatható az arany értékelése.

Ismételten szögezzük le: mindennek megvalósításához egy élő és aktív Keynes kellett volna, ő azonban meghalt, így mindez írott malaszt maradt, és a Valutaalap eredeti rendszere a szükséges árfolyamváltozások és az arany értékelésének megváltoztatása nélkül összeomlott.

\section{Az IMF alapító szerződése ${ }^{11}$}

A közös nyilatkozatban kifejtett elvek szinte változatlanul megjelennek az alapító szerződés cikkeiben is. Keynes tehát, még ha le kellett is mondania a nemzetközi pénzröl, a bancorról, és el kellett is fogadnia az arany-dollár-standardot ennek

${ }^{11}$ Az 1944. július 22-én kelt Bretton Woods-i megállapodás cikkeinek rövidített szövegét a tanulmány elektronikusan közölt Mellékletének M5. szemelvénye közli. A teljes szöveg is elérhetö: Joint Statement [1944]. 
minden veszélyével együtt, Bretton Woodsban olyan művet és olyan rendszert hagyott az utókorra, amely lehetővé tette volna egy mainál jobb nemzetközi pénzügyi világrend kialakítását.

Az I. cikk szerinti célkitüzések gyakorlatilag azonosak a közös nyilatkozatban foglaltakkal, sőt akár radikálisabbak azoknál. Az alapvető cél „a nemzetközi monetáris együttmüködés” és ,a nemzetközi kereskedelem bővülésé[nek] és kiegyensúlyozott növekedésé[nek]”, valamint „a foglalkoztatottság és a reáljövedelem magas szintjének előmozdítása"; ez utóbbi alapvető cél itt még határozottabb formában szerepel, mint a közös nyilatkozatban. Ugyanilyen határozottsággal szerepel, hogy ez a rendszer lehetővé teszi a tagok számára, hogy „fizetésimérleg-zavaraikat olyan intézkedések foganatosítása nélkül küszöböljék ki, amelyek károsan hatnak a nemzeti vagy a nemzetközi jólétre". Hol van ez attól, ami megvalósult, hogy a Valutaalap olyan intézkedések elsődleges pártolójává, sőt kikényszerítőjévé vált, amelyek nyilvánvaló módon „károsan hatnak a nemzeti vagy a nemzetközi jólétre”? Végül az szerepel a célkitüzések között, hogy a Valutaalap „a nemzetközi monetáris problémákról folytatott eszmecserék és együttmüködés szervezetéül szolgál". Ez egyértelmüen a független államok önkéntes együttműködését hangsúlyozza, mert az „eszmecserék és együttmüködés szervezete", amit Keynes óhajtott, valami egészen más, mint az a nemzetközi, sőt nemzetek feletti pénzügyi rendőrség, amely sajnos létrejött.

A III. cikk megállapítja az alapító tagok kvótáit, amelyek meghatározzák mind az Alap tevékenységének, azaz hitelnyújtásának lehetőségeit, mind pedig az Alapon belüli hatalmi viszonyokat, mert a szavazatok aránya a kvóták arányától függ. A megállapodás szerint a konferencián képviselt és a feltételezések szerinti alapító tagok kvótája a következö lett volna:

\begin{tabular}{lc}
\hline Ország & Millió dollár \\
\hline Egyesült Államok & 2750 \\
Egyesült Királyság & 1300 \\
Szovjetunió & 1200 \\
Kína & 550 \\
Franciaország & 450 \\
India & 400 \\
Más alapító államok & 2150 \\
Összesen & 8800 \\
\hline
\end{tabular}

Ezek az értékek két alapvető fontosságú szempontból felelnek meg a keynesi elgondolásoknak. Egyrészt az alapító tagok összesen 8,8 milliárd dollár jegyzését további államok belépése mintegy 10 milliárd dollárra egészítette volna ki a szervezet alaptőkéjét, ami a White-tervben eredetileg szereplő 5 milliárd kétszerese, vagyis a nemzetközi hitelnyújtási lehetőségeknek az eredeti amerikai elképzelésekkel szembeni megkétszerezése. Másrészt a legnagyobb kvótájú és hatalmú öt ország azonos az ENSZ Biztonsági Tanácsának öt állandó tagjával, és közülük a legnagyobb három, az Egyesült Államok, az 
Egyesült Királyság és a Szovjetunió kvótája külön-külön meghaladja az összes jegyzés 10 százalékát, éles ellentétben a White-terv vonatkozó javaslatával. Ez azt jelenti, hogy a legalapvetőbb döntések, így a dollár-arany értékarány tekintetében a Szovjetuniónak vétójoga lett volna éppúgy, mint ahogy Oroszországnak ma is vétójoga van az ENSZ Biztonsági Tanácsában. Keynes joggal tételezte fel, hogy ilyen körülmények között a Szovjetunió részt fog venni az Alapban, amit a leghatározottabban óhajtott. Fontos még India 400 milliós kvótája. Ez azt mutatja, hogy Indiát független és vezető országként kezelték már akkor, valamint azt a törekvést, hogy a fejlődő országok megkapják a világ irányításában a nekik kijáró helyet, ami mindmáig nem történt meg.

Ugyanez a III. cikk a közös nyilatkozattal összhangban a befizetési kötelezettség dollárban vagy aranyban teljesítendő részét az országok dollár- és aranytartalékának 10 százalékában maximálja, és a fennmaradó részt az országoknak saját valutájukban (és nem kamatozó kötvényeikben stb.) kell befizetniük. Ez a legszegényebb országokra sem ró nehezen teljesíthető terhet, és nincs restriktív hatása. Végül e cikk elöírja, hogy „a Kormányzótanács ötévenként felülvizsgálja a tagok kvótáját, és amennyiben ezt indokoltnak tartja, javasolja a tagok kvótájának kiigazítását". Valóban többször is sor került a kvóták kiigazítására, de távolról sem a világban bekövetkezett politikai és gazdasági súlyarányok megváltozásának megfelelő mértékben.

A IV. cikk, ismét a közös nyilatkozattal összhangban, nem vitatva, hogy a valutastabilitás kívánatos, a valutaparitás megváltoztatását alapvető egyensúlyzavar esetén a gazdaságpolitikai eszköztár szerves részének tekinti, és elsődlegesen a tagállamok hatáskörébe utalja azzal, hogy ez csak az érintett tag javaslatára és az Alappal való konzultáció után hajtható végre. A szöveg szerint az Alap nem kifogásolhat 10 százalékot meg nem haladó, tehát csekély változtatást, és ennél nagyobb javasolt változtatás esetén gyakorlatilag haladéktalanul közölnie kell esetleges kifogásait. Megjelenik, ismét a közös nyilatkozattal a legteljesebb összhangban, az arany valutában, nyilván elsősorban dollárban kifejezett értékének módosítási lehetősége is, ha ezt a vezető országok elfogadják. Tudjuk, hogy Keynes - szerintem méltatlan - utódai a valuták értékarányának módosítási lehetőségével alig, az arany értékelésének módosítási lehetőségével pedig egyáltalán nem éltek, aminek meg is lett a következménye.

A VI. cikk - ismét minden korábbi keynesi anyaggal összhangban - kimondja, hogy az Alap eszközei nem használhatók fel „nagyarányú és tartós jellegü tőkekiáramlás fedezetéül”, továbbá , a tagok a nemzetközi tőkemozgások szabályozásához szükséges ellenőrzést folytathatnak, de [nem úgy, hogy ez] a folyó müveletekkel kapcsolatos fizetéseket korlátozza”. Ezt kiegészíti a VII. cikk, amely szerint az Alap „a szűkös valutából meglévő és birtokába kerülő készletét arányosan eloszt[hat]ja”, ugyanakkor „bármely tag [...] az Alappal való konzultációt követően időlegesen korlátozásokat vezet[het] be a szükében lévő valutában bonyolódó devizamüveletek szabadságát illetően”. Nagyon fontos az Alappal való konzultáció kikötése és így a nemzetközi pénzügyi rend rombolásának elkerülése, de nem kevésbé fontos, hogy a fizetési nehézségekkel küszködö tagnak meg kell adni a lehetőséget, hogy időlegesen korlátozásokat vezessen be, és ne folyamodjon restrikcióhoz és a jólét csökkentéséhez, ami bizony jelenleg szinte az egyetlen rendelkezésére álló eszköz. Itt kell tárgyalnunk a VIII. cikket is, amely a tagok általános kötelezettségeit egészen szük körre szorítja, és szó sincs arról a széles körü kon- 
dicionalitásról, amely később a Valutaalap tevékenységének szinte az alapelemévé vált. Idetartozik a XV. cikk is, amely szerint „bármelyik tag bármikor kiléphet az Alapból”, ami biztosítja, hogy az Alap mindenkor a tagok - és egyben az egész nemzetközi közösség - érdekében járjon el. Ez nyilván nehéz feladat, de az Alap létezését csak ennek a nehéz feladatnak a megoldására való törekvés indokolhatja.

A fenti végtelenül pozitív és a legteljesebb mértékben keynesi szellemü rendelkezések mellett valóságos taposóaknák is belekerültek a megállapodásba. A IX., a XII. és a XIII. cikk egyes rendelkezései tekinthetők ilyennek. A IX. cikk szerint „valamennyi tag biztosítja az Alap számára [az e] cikkben meghatározott jogállást, mentességeket és kiváltságokat". Ez az előkészítés során alig tárgyalt cikk elvben nem kifogásolható, de a későbbiekben hozzájárult ahhoz, hogy az Alap és tisztviselői a tagállamok fölött állónak érezhessék magukat. A XII. cikk szerint „az Alap kormányzótanácsból (Board of Governors), ügyvezető igazgatóságból (Executive Directors), egy vezérigazgatóból (Managing Director) és a tisztviselői karból áll”. Ez ismét nem kifogásolható, e cikk azonban nem határozta meg a részleteket, és ez már Savannah-ban e taposóakna robbanására, hatalmas összeütközésekre vezetett. Végül a XIII. cikk úgy rendelkezik, hogy „az Alap központja a legnagyobb kvótával rendelkező tag területén müködik"; ami ismét elfogadható, föként azért, mert ennek az országnak a területére került az ENSZ székhelye is. Közvetlenül Savannah elött kiderült azonban, hogy ezt a rendelkezést a legnagyobb kvótával rendelkezö tag úgy értelmezi, hogy egyedül és szabadon határozhatja meg, hogy mely városban legyen az Alap központja.

\section{Összefoglalás}

Ez a cikk a Valutalap megalakítására vezetö hat legfontosabb dokumentumot ismerteti, Keynes és White két tervezetét, valamint az ezek egyeztetésének eredményeként létrejött két záródokumentumot. Bemutatja, hogy Keynes eredeti terve életmüvének betetőzése, ugyanolyan súlyú, mint a keynesi általános elmélet, és joggal nevezhető a keynesi általános nemzetközi elméletnek. Az egyeztetés során Keynesnek el kellett fogadnia az általa javasolt nemzetközi pénz, a bancor helyett az arany-dollárstandardot, de mégis olyan rendszert sikerült létrehoznia, amely elvben lehetővé tette volna az elképzelései szerinti nemzetközi rend kialakítását. Erre mégsem kerülhetett sor. Elképzelései súlyos sebet kaptak a Bretton Woodsban nem tisztázott kérdéseket megoldó savannah-i értekezleten, és megvalósításuk lehetetlenné vált halála miatt. Mindez mérhetetlen károkat okozott a világ egészének, és a jövőben törekednünk kell Keynes eredeti és ma is időszerű elgondolásainak megvalósítására.

\section{Hivatkozások}

Akerlof, G. A.-Shiller, R. J. [2009]: Animal Spirits. How Human Psychology Drives the Economy, and What it Matters for Global Capitalism. Princeton University Press, Princeton and Oxford, xiv +230 o. 
Articles of... [1944]: Articles of Agreement of the International Monetary Fund (22 ${ }^{\text {th }}$ July, 1944). Megjelent: Horsefield [1969b] 185-214. o.

BeKker Zsuzsa (szerk.) [2005]: Közgazdasági Nobel-díjasok, 1969-2004. KJK-Kerszöv, Budapest, 928 o.

Bentley, E. [1952]: Out of Bondage. Hart-Davis, London.

Boughton, J. M. [2002a]: Why White, Not Keynes. Inventing the Postwar International Monetary System. IMF Working Paper WP/02/52. IMF, Washington, D.C. 24 o.

Boughton, J. M. [2002b]: American in the Shadows. Harry Dexter White and the Design of the International Monetary Fund. IMF Working Paper WP/06/6. IMF, Washington, D.C. 19 o. Chambers, W. [1952]: Witness. Random House, New York.

Fleming, M. [1962]: Domestic Financial Policies Under Fixed and Under Floating Exchange Rates. International Monetary Fund Staff Papers, 9, 369-379. o.

Harrod, R. [1982]: The Life of John Maynard Keynes. Norton, New York-London, 672 o.

Horsefield, J. K. [1969a]: The International Monetary Fund 1945-1965. Twenty Years of International Monetary Cooperation. Volume I: Chronicle. International Monetary Fund, Washington, D.C., xviii + 663 o.

Horsefield, J. K. [1969b]: The International Monetary Fund 1945-1965. Twenty Years of International Monetary Cooperation. Volume III: Documents. International Monetary Fund, Washington, D.C., vii + 549 o. http://www.elibrary.imf.org/staticfiles/IMF_History/ IMF_45-65_vol3.pdf.

Joint Statement [1944]: Joint Statement by Experts on the Establishment of an International Monetary Fund (7 $7^{\text {th }}$ April, 1944). Megjelent: Horsefield [1969b] 128-135. o.

Keynes, J. M. (1919/1971): The Economic Consequences of the Peace. Megjelent: The Collected Writings of John Maynard Keynes. Vol. 2. Macmillan-St Martin's Press for the Royal Economic Society, London-Basingstoke, xxv + 192 o.

Keynes, J. M. [1906-1946/1971-1989]: The Collected Writings of John Maynard Keynes. Vol. 1-30. Macmillan-Cambridge University Press for the Royal Economic Society, LondonBasingstoke.

Keynes, J. M. [1913]: Indian Currency and Finance. Macmillan, London, viii + 263 o.

Keynes, J. M. [1930]: A Treatise on Money. Vol. 2. The Applied Theory of Money. Macmillan, London, viii $+424 \mathrm{o}$.

Keynes, J. M. [1936/1965]: A foglalkoztatás, a kamat és a pénz általános elmélete. Közgazdasági és Jogi Könyvkiadó, Budapest 432 o.

KeYneS, J. M. [1940-1944/1980]: Activities 1940-1944. Shaping the Post-War World: The Clearing Union. Megjelent: Moggridge, D. (szerk.): The Collected Writings of John Maynard Keynes. Vol. 25. Macmillan-Cambridge University Press for the Royal Economic Society, London-Basingstoke, xiv + 522 o.

Keynes, J. M. [1941-1946/1980]: Shaping the Post-War World: Bretton Woods and Reparations. Megjelent: The Collected Writings of John Maynard Keynes. Vol. 24. Activities 1941-1946. Macmillan-Cambridge University Press for the Royal Economic Society, London-Basingstoke, xiii +453 o.

Keynes, J. M. [1941a]: Draft Statement (30 ${ }^{\text {th }}$ January.) Megjelent: Keynes [1940-1944/1980] 11-16. 0 .

Keynes, J. M. [1941b]: Post-War Currency Policy ( $8^{\text {th }}$ September). Megjelent: Keynes $[1940-$ 1944/1980] 21-40. o.

Keynes, J. M. [1941c]: Proposals for an International Currency Union (20 ${ }^{\text {th }}$ November). Megjelent: Keynes [1940-1944/1980] 43-66. o. 
Keynes, J. M. [1942a]: Plan for an International Currency (or Clearing) Union (25 $5^{\text {th }}$ January). Megjelent: Keynes [1940-1944/1980] 108-139. o.

Keynes, J. M. [1942b]: Proposals for an International Currency (or Clearing) Union (11 ${ }^{\text {th }}$ February). Megjelent: Horsefield [1969a] 3-18. o. http://imsreform.imf.org/reserve/pdf/ keynesplan.pdf.

Keynes, J. M. [1942c]: Proposals for an International Clearing Union (28th August). Megjelent: Keynes [1940-1944/1980] 168-204. o.

Keynes, J. M. [1943]: Proposals for an International Clearing Union. (The White Paper) $\left(7^{\text {th }}\right.$ April.) Megjelent: Horsefield [1969a] 19-36. o.

Keynes, J. M. [1944-1946/1979]: The Transition to Peace. Megjelent: Moggridge, D. (szerk.): The Collected Writings of John Maynard Keynes. Vol. 24. Macmillan-Cambridge University Press for the Royal Economic Society, London-Basingstoke, xiv + 690 o.

Madarász Kristóf-Vincze János [2005]: George A. Akerlof (1940-). Megjelent: Bekker [2005] 775-787. o.

Moggridge, D. E. [1992]: Maynard Keynes. An economist's biography. Routledge, LondonNew York, $31+941$ o.

Moggridge, D. E. [1993]: Keynes. 3. kiadás, Macmillan, viii + 190 o.

Mundell, R. A. [1963]: Capital Mobility and Stabilization Policy under Fixed and Flexible Exchange Rates. Canadian Journal of Economic and Political Sciences, Vol. 29. No. 4. 475-485. o.

North, D. C. [2005]: Understanding the Process of Economic Change. Princeton University Press, Princeton-Oxford, 187 o.

ReEs, D. [1973]: Harry Dexter White. A Study in Paradox. Coward, McCann and Geoghegan, New York, 506 o.

Skidelsky, R. [1992]: Hopes betrayed. 1883-1920. John Maynard Keynes. Vol. I. Macmillan, London, xxviii $+447 \mathrm{o}$.

Skidelsky, R. [2000a]: The Economist as Saviour. John Maynard Keynes. Vol. II. 1920-1937. Macmillan, London, xxxv +731 o.

Skidelsky, R. [2000b]: Fighting for Britain 1937-1946. John Maynard Keynes. Vol. III. Macmillan, London, xxiii + $580 \mathrm{o}$.

Skidelsky, R. [2005]: John Maynard Keynes 1883-1946: Economist, Philosopher, Statesman. Penguin, London, xxxi + 1021 o.

Sudoplatov, P.-Sudoplatov, A. [1994/1995]: Special Tasks. The Memoirs of an Unwanted Witness - a Soviet Spymaster. Updated Edition. Little, Brown and Company, Boston, 527 o.

Sza KolczaI GyöRgY [2016]: Keynes életútja és a Nemzetközi Valutaalap létrehozására vezető gondolatai. Közgazdaság Szemle, 63. évf. 7-8. sz. 838-857. o. http://dx.doi.org/10.18414/ KSZ.2016.7-8.838.

VRies, De, M. G.-Horsefield, J. K. [1969]: The International Monetary Fund 1945-1965. Twenty Years of International Monetary Cooperation. Volume II. Analysis. International Monetary Fund, Washington, D.C., 621 o.

White, H. D. [1933]: The French International Accounts, 1880-1913. Harvard University Press, Cambridge, Mass.

White, H. D. [1934]: Selection of a Monetary Standard for the United States. Report submitted to Jacob Viner. U.S. Treasury, 22 September, Harry Dexter White Papers, Princeton University, Princeton, N.J.

White, H. D. [1942]: Preliminary Draft Proposal for a United Nations Stabilization Fund and a Plan for Reconstruction and Development of the United and Associated Nations 
(April). Megjelent: Horsefield [1969b] 37-82. o. http://www.imsreform.org/reserve/pdf/ whiteplan.pdf.

White, H. D. [1943]: Preliminary Draft Outline of a Proposal for an International Stabilization Fund of the United and Associated Nations. (Revised $10^{\text {th }}$ July 10). Megjelent: Horsefield [1969b] 83-96. o.

\section{Függelék}

\section{Az elektronikusan elérhetö Melléklet tartalma}

M1. A Keynes-terv első változata. The Keynes Plan. Proposals for an International Currency (or Clearing) Union (February 11, 1942). Megjelent: Horsefield [1969b] 3-18. o.

M2. A White-terv első változata. The White Plan. Preliminary Draft Proposal for a United Nations Stabilization Fund and a Bank for Reconstruction and Development of the United and Associated Nations (April 1942). Megjelent: Horsefield [1969b] 37-82. o.

M3. A Keynes-terv második változata. [The] Keynes Plan. Proposals for an International Clearing Union (White Paper) (April 1943). Megjelent: Horsefield [1969b] 19-36. o.

M4. A White-terv második változata. [The] White Plan. Preliminary Draft Ouline of a Proposal for an International Stablization Fund of the United and Associated Nations (April 1942). Megjelent: Horsefield [1969b] 83-96. o.

M5. A közös nyilatkozat. Joint Statement by Experts on the Establishment of an International Monetary Fund (April 1944). Megjelent: Horsefield [1969b] 128-135. o.

M6. A Valutaalap alapszerződése. Articles of Agreement of the International Monetary Fund (July 22, 1944). Megjelent: Horsefield [1969b] 185-214. o. 